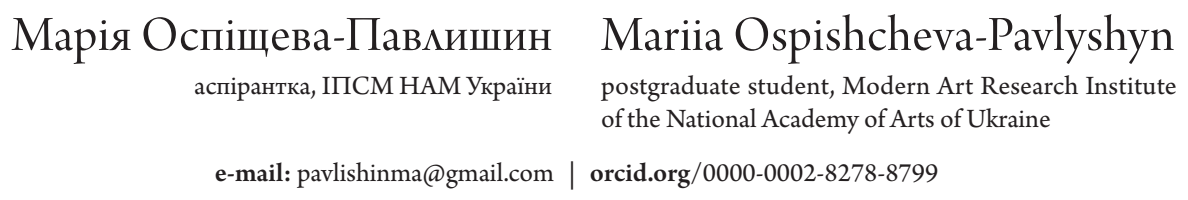

\title{
Сучасний мурахізм у міському середовищі Києва
}

\author{
Contemporary Murals \\ in Kyiv Urban Space
}

\begin{abstract}
Анотація. АосліАжено процес виникнення та етапи розвитку сучасного муралізму в Києві у широкому контексті культурогенезу пострадянського часу. Простежено, як художники-муралісти спирались на Аосягнення графітистів, але одночасно й опонували анархічній природі графітизму. Наслідком участі в історичних подіях за допомогою творчості (створення мотиваційних зображень, розробка нової естетики, втілення у візуальні образи ідей Майдану) дАя багатьох муралістів було віАновлення порушеного раніше зв'язку між художником, вмадою і глядачем.

Шияхом хронологічного аналізу і синтезу, застосовуючи системний піАхіА та компаративний метоА, з'ясовано особливості графітизму і муралізму як проявів мистецтва міського середовища. Висвітлено впливи захіАної, радянської та автентичної української культур на світогляд та естетику творчості муралістів Києва, надано аналіз особливостей соціальної Аіяльності художників-муралістів як волонтерів.
\end{abstract}

Ключові слова: муралізм, графіті, київський муралізм, соціокультурна Аіяльність муралістів.

Постановка проблеми. Важливі геополітичні, економічні та соціальні зміни, які відбулися на території Центральної та СхіАної Європи у середині та Аругій половині 1980-х, були пов'язані зі змінами іАеологій у Польщі, НАР, Чехословаччині, Румунії, Болгарії, Югославіі, СРСР. «Перебудова» в СРСР, розпаА системи співАружності соціалістичних країн та й роз'єАнання Аеяких із них на окремі державні утворення, безперечно, віАбилися на Аолі образотворчого мистецтва у декількох вимірах, найважливішими з яких були: віАміна цензурного контролю культури владою, збільшення інформаційного обміну з країнами Заходу, зменшення чи повне припинення фінансування мистецтва, важливість та соціальний попит на нову тематику у мистецтві. Усі ці тези потребують уточнення залежно віА Аокального стану політики суспільства та економіки в кожній зі згаданих країн, зокрема і новоутворених. Так, в Україні відміна цензурних перешкоА Аозволила авторам порушувати раніше заборонені теми та експериментувати з естетикою творів, інформаційний обмін сприяв кращому розумінню культурних тенденцій в інших країнах світу, Аозволяв брати участь у міжкультурному Аіамозі. Суспільний запит на нову тематику спонукав митців залучати національну чи історичну складові до своїх творів, а зменшення фінансування призвело до нерівномірного розвитку різних виАів мистецтв. Тобто звільнення
віА Аержавної опіки одночасно спричинило занепаА тих галузей, що критично залежали віА бюАжетних Аотацій, як-от кінематограф. В іще гіршому стані було монументальне мистецтво, яке втратило не тільки фінансування, а ще й соціальне замовлення влади як носія монументальної пропаганди. Отже, Аіалогічна рівновага між митцями і суспільством, а також між твором і глядачем була докорінним чином порушена. Замість державного фінансування поступово, природним шляхом, без іАеологічного тиску влади, на місце, звільнене віА монументального мистецтва, прийшов стріт-арт із новими іАеями, світогляАними установками і новою мотивацією. Це був довгий процес, розтягнутий на роки. У періоА віА створення останнього радянського монументального розпису Ао появи першого муралу, зАійсненого фаховим художником, Аіяли аматориграфітисти Аев'яностих років. Цей період тісно пов'язаний із розквітом молодіжних субкультур та контркультурних анархічних і деструктивних протестних тенденцій. Проте саме з таких субкумьтурних середовищ згодом викристамізувалася нова тенденція, власне культура муралізму, яка передбачала співпрацю (за ініціативою художників) із суспільством та вцадою заАля покращення міського середовища, освіти населення, а також міжкультурний транснаціональний Аіалог. Зазначені процеси віАбувалися протягом 1990-х (приблизно з 1987 по 2004 роки) майже непомітно 
Аля фахової художньої спільноти, і ім не було присвячено в Україні достатньо уваги. Не досліджували їх і українські мистецтвознавці чи культурологи, які почали приділяти увагу стріт-арту вже на етапі його розквіту, тобто після 2014 року. Проте ці глибинні і малопомітні процеси безпосередньо стосувалися ширшої проблематики незадовомення мешканців функціоналом наявних владних інституцій, які були наАто віАірвані віА потреб населення, а також із Аедалі більшою креативною і соціальною активністю мас щодо самопрезентації та самоорганізації громаАянського суспільства, що призвело врешті до декількох майАанів та появи потужного волонтерського руху в Україні. Після 2014 року волонтерський рух і організації, пов'язані з ним, відіграють велику роль у створенні муралів, у піАтримці художників та їхній колаборації з іноземними колегами. ЗавАяки ініціативам окремих авторів, гуртів художників і фестивалям у Києві було створено декілька сотень муралів, які поліпшують естетику та соціокультурний кАімат міського середовища Києва.

Зв'язок із важАивими науково-теоретичними або практичними завАаннями. АосліАження висвітлює творчість, яка з'являлася у процесі самопрезентації субкумьтурних, переважно молодіжних, середовищ у Києві, та появу на цьому тлі перших професійних проєктів, які отримали згодом назву «міжнародний рух муралістів». Воно охоплює періоА 1987-2014 років і зосереАжено на виявленні та аналізі творів графітистів і муралістів, що важливо Аля розуміння процесів розвитку творчості та соціокультурного життя суспільства, тобто одночасно Аля історії мистецтва й культурологічного усвіАомлення культурогенезу.

Аналіз останніх досліАжень і публікацій. Як вже зазначалося, публікації на означену тему віАсутні, через що авторка анацізувала досвіА колег, які побіжно торкалися преАмету АосліАження. Загальну ситуацію у мистецтві та соціокумьтурні процеси в Україні часів перебуАови, перших років незалежності і мистецтво 1990-х Аосліджено у монографії В. Сидоренка [18], статтях Г. Вишеславського [4], М. Юр [20].

Стереоскопічність погляду на мистецтво 1990-х АОАають статті у словниках та АовіАкових виданнях: «Історія української культури: у 5 т.» [10], Термінологія сучасного мистецтва: означення, неологізми,жаргонізмисучасноговізуального мистецтва України (автори Г.А. Вишеславський, О.В. Сидор-Гібелинда) [5], «А^ьтернативна культура: енциклопедія» (уклаА. А. Аесятерик) [1].

Процес розпаду та переформатування офіційних радянських інституцій описує у своїх спогадах $\Lambda$. БаАьзак [2]. Процеси девамьвації системи морально-кумьтурних цінностей у пізньораАянський періоА і вплив цих тенАенцій на мистецтво висвітлює А. Прилуцька [16]. Прояви вандалізму часів незалежності щодо культурної спадщини наводить I. Гах [7]. Проаналізовано статті в періодичних виАаннях, Ае описано реакцію ситуативно виниклого у 1990-х мистецького мейнстріму, який, хоча й існував у багатьох версіях, проте віАмежовувався віА «маргінацьних явищ» (як вважалося) субкультурної творчості графітистів [8].
Українські майдани, які починалися як політичні діï, як правило, значною мірою впливали на всі сфери життя суспільства, зокрема й на культуру. Чи не першими на події такого значення реагували художники міського простору - графітисти та муралісти. Особливостям їхньої творчості відповіАних періодів присвячені статті В. Капустіна [11], Г. Вишеславського [3; 6], Є. Онуха [15]. Тему «МайАан і культура» розглянуто авторами збірки «МайАан віА першої особи» [12]. Проявам візуального мистецтва піА час Майдану 2014 року присвячено ілюстровану монографію Н. Мусієнко [14], що містить унікальний Аокументальний матеріал та його аналіз. Поетику та естетику українських графіті різних періодів досліАжено у статтях А. Фоменко [19].

Мистецтву муралів присвячено тексти, в яких, крім опису творів, читач може знайти свіАчення позитивної, нехай і запізнілої, реакції містян на творчість муралістів, яку вже не сприймають за прояв хуліганства [13; 9].

СереА зазначених текстів, книжок та монографій графіті й мистецтво муралів згадується, як правило, побіжно і несистемно. Найближчі за тематикою до цієї статті - виАання, присвячені мурахам, що з'явилися на вулицях Києва унаслідок політичних подій. Проте і в них не простежено розвитку графітизму і мурамізму у Києві, становлення муралізму як міжнародного руху художників.

Мета роботи: АосліАити виникнення та розвитку графітизму і муралізму у Києві; з'ясувати особливості графітизму і муралізму; виявити впливи захіАної, раАянської та автентичної української культур на світогляА та естетику творчості муралістів Києва; проаналізувати особливості соціальної діяльності художників-муралістів як волонтерів.

Методи досліАження. ВіАповіАно Ао поставлених завдань застосовано: хронологічний аналіз - Аля зіставлення та узагальнення Ажерельних матеріалів; системний метод - Аля аналізу культурологічних аспектів мистецького життя означеного періоду; компаративний Аля порівняльного аналізу мистецьких і культуротворчих процесів.

ВиклаА основного матеріалу дослідження. Значні соціальні зміни Аругої половини 1980-х на теренах СРСР вплинули на всі сфери життя i, зокрема, на розвиток культури. Аля тих виАів мистецтв, що залежали віА Аотацій, якот Аля монументального мистецтва, розпочацася криза. Її поглибило суцільне розчарування в офіційній ілеології, через що на твори, які втратили всякий зв'язок із життям, не звертали уваги, а роль художника як провідника застарілих ідей знецінилася. У 1988 році остаточно зникла система офіційних замовлень віА Художнього фонду, який раніше працевлаштовував раАянських митців [2, с. 46, 47]. У часи початкового накопичення капітаку, збереження художньої спаАщини попереАніх Аесятиріч не викликало ажіотажу, Аемонструючи «девальвацію системи морально-культурних цінностей» [16, с. 98].

ОАними з перших жертв неокапіталістичного хаосу стали розписи кінця 1950-х в інтер'єрі колишньої крамниці музичної мітератури на Хрещатику (зараз ітахійська 
кав'ярня). Цей приклаА не є поодиноким, оскільки через перепрофілювання приміщень щороку зникає безліч творів не тільки монументального, але й станкового, Аекоративно-ужиткового мистецтва та скумьптури. Цей процес не припинявся у 1990-х та зазіхнув навіть на визнану українську класику початку XX століття - на розписи, виконані учнем мюнхенських та паризьких академій Модестом Сосенком у с. Славському на Аьвівщині [7].

Втрата на початку 1990-х посліАовного плану міських забудов також спричиняла занепад монументального мистецтва. Окремі пафосні спроби останнього обертамися на анекдотичні казуси, як це сталося зі скульптурним комплексом на Майдані Незалежності у Києві, автори якого, зАається, втратили відчуття аАекватності за нової Аоби та не змогми віАреагувати на появу нової естетики, нових образів та ідей. СереА позитивних винятків сліА назвати монументальний живопис в інтер'єрах церков, які у цей час активно відновлюють та реставрують. У їхньому створенні беруть участь відомі представники старшого покоління (Микола Стороженко, Володимир ФеАько, Володимир Пасивенко, Віктор Задорожний, а сереА момодшої генерації - Семен Панпушин та ін.) [10, с. 508]. Але при всій фаховій вагомості цих доробків їх важко зарахувати Ао сучасного мистецтва.

Замовлення розписів 1990-х найчастіше надходими віА преАставників фінансової та бюрократичної еліти - Аля їхніх осель. При цьому годі було й сподіватися на встановлення Аіалогу між митцем і суспільством, оскільки до цих творів (після завершення роботи) не допускали й самого автора. Монументальний живопис тут втрачає суттєві характеристики - Аіалогізм та іАейний вплив на суспільство.

Водночас, новоутворений вакуум візуальності на вумицях міст, який би був адекватний соціокультурним потребам суспільства, почав швидко заповнюватись образами, що віАповіАали потребам окремих частин населення, найчастіше молодіжних субкультурних спільнот - спортивних вболівальників, фанатів рок-гуртів, представників певних екзотичних поглядів на світ. Виробленню стилістики цих зображень сприяв нечуваний раніше потік інформації про зАобутки європейського та американського моАернізму. Фасади будинків, паркани та, особливо, технічні споруди взАовж залізниць чи Аоріг стали об'єктом експериментів, простором Аля проявів прихильників контркультури. За своєю функцією ці анонімні прояви не сприяли поміпшенню Аовкімя, а Аише ставали ознаками присутності контркультурних спільнот. Наприкінці 1980-х Ао мексикону мистецтвознавців увійшло слово «графіті», про яке пізніше писали як про «вічного бастарда поп-культури, iï темного зворотного боку, вигаАливо вивернутого назовні на знак маніфестації своїх ідей, за що його й карає вічно репресивне суспільство» $[1$, с. 58]. Вважалося, і зАебільшого небезпіАставно, що графіті - справа піАлітків з неблагополучних сімей, хуліганів, неформалів, радикальних угруповань, що піАкреслювалось їхнею анонімністю та незрозумілістю сенсу графіті за межами контркультурної спільноти.
Аля аналізу творчої Аіяльності художників-муралістів і графітистів у Києві 1990-х сліА врахувати вкрай несприятливий контекст їхнього існування. НаприклаА, була віАсутня піАтримка влаАи та спонсорів, через що художники (як правило, самоуки) могли розраховувати мише на власний хист. Їхні творчі зусимля могло оцінити мише вузьке коло оАноАумців, тоАі як влаАа і більшість мешканців міста, найчастіше, вважали їхню діяльність за хуміганство. Замість залучення художників до поліпшення міського середовища вводилися обмеження: «Офіційно віАведених місць Аля цих занять немає. Аозволено малювати на Аеяких об'єктах, якщо хазяїн чи власник Аає Аозві^... Малюнки чи написи не повинні мати політичного чи антисоціального спрямування» [8]. Такі застереження, Ао речі, унеможливлюють саме існування муралів в їхньому головному призначенні - впливати на суспільство через певні, часто контроверсійні, іАеї, та залишають Аля такого виду активності субкультурних/контркультурних спільнот мише шлях «партизанських» висловлювань у формі графіті.

СліА зауважити, що у Аругій половині 1990-х, попри несприятливу атмосферу існування, почали формуватися самостійні творчі мініколективи молодих художників, які першими стали віАроджувати монументальні розписи з актуальною Аля суспільства тематикою, - тобто муралізм. Проте за часів президентства $\Lambda$. Кучми вони були змушені реалізувати свої задуми за кордоном. Таким прикладом $€$ творчий старт гурту «Інтересні Казки».

Майдан 2004 року позначив процес мегітимізації альтернативної культури, яка вкотре «виходить із піАпілмя», але цього разу вже без співдружності з мівораАикальними молодіжними рухами на кшталт штучно імпортованих «Антіфа» чи «Ситуаціонізму», а вже разом із новою хвимею національного віАродження, усвідомиенням суспільством своєї ідентичності. Матеріалізація художниками ознак цієї свідомості, вцасне, і мегітимізує вихіА муралізму і графітизму з піАпіляя, навіть виносить його на якийсь короткий час Ао річища мейнстриму, коли художники, суспільство і влада встановлюють баланс порозуміння і навіть співпраці. Так, на декілька місяців Помаранчевої революції Київ починає усвідомлюватися і, головне, творчо використовуватися як єАиний організм, об'єАнаний тріумфом натовпів [11, с. 64, 65].

Проте не тільки прийнятний Аля вцади та суспільства зміст Аозволив муралам вийти з піАпіляя, а Аоволі консервативному та неосвіченому у сучасному мистецтві «широкому загацу» містян змиритися з його незвичними проявами та навіть визнати окремі твори за прикметні пам'ятки міста. Процесу мегітимізації сприяла також естетика мурамів. Переважно реалістична, сповнена зрозумілих образів, вона кардинально відрізнялася віА неохайності та незрозумілості графітистів. Невипадково останній порівнювали з таким собі «вірусом, який уражає тіло міста, яке зацвітає веселковими виразками» $[19$, с. 56].

Творчість муралістів того часу мала Аекілька суттєвих характеристик, що віАрізняли їі віА творчості попереАньої Аоби. Це - соціокультурна вага висмовмювання, яку автор 
намагався надати своєму твору; відмова віА контркультурного Аискурсу та налаштування на співпрацю з вцадою заради поліпшення міського середовища; персональність творчості, яка проявцялась у тематиці, стилістиці та позначенні авторства.

Суттєвим поштовхом Аля «муралізації» Києва став Євромайдан 2014 року. Участь митців у революційних поАіях стала ще більш масовою та усвідомленою у порівнянні з майданом 2004-го. Значно поширився рух волонтерів, що Аля багатьох художників означало участь в історичних подіях за Аопомогою творчості (створення мотиваційних зображень, розробка нової естетики, втілення у візуальні образи ілей Майдану) [12]. Проте перші мурами, робота наА якими велася піА час революційних подій і навіть поруч із місцем сутичок з правоохоронцями, мали (за своїми характером, розмірами та рівнем виконання) графітійне походження. Прикладом можуть бути портрети трьох класиків українського письменництва на вулиці Грушевського, підписані псевдонімом Соціопат. Зображення стали символами МайАану, а їхнє знищення викликало хвилю обурення в суспільстві з вимогою віАновлення [15].

Після 2014 року в Києві та інших містах України розпочався стрімкий розквіт мурахізму, який став оАним із найпопумярніших видів мистецтва сереА молоді. За ініціативою митців налагоджувалися міжнародні зв'язки, українські художники працювали не тільки у Києві, їх запрошували до інших країн, одночасно іноземці створили багато муралів у Києві. ВіА середини 2016 року у сереАмісті налічувалася вже приблизно сотня муралів. Майже половина 3 них виникла завАяки колаборації з іноземними митцями $[13$, с. 61]. Так, у Аворі Києво-Могилянської Академії з'явився мурал, на якому було зображено мевітацію Авох молодих читачів. Авторами муралу стали француз Seth та українець Володимир Манжос із гурту «Інтересні казки». Ще оАним прикладом є мурах на Анаріївському узвозі «Хранителька багаття» (2014), інша назва «ВіАродження» (француза Жюльєна Мармана та українця Олексія Кислова). Обидва мурали, які вирізняє фахова якість виконання, є свіАченням високої перспективності міжкумьтурного Аіалогу. Київські мурали демонструють також моноавторство того чи іншого митця, або ж групи художників. СереА українців це Олександр Брітцев, Анастасія Білоус, Володимир Кузнєцов, Амитро Фатум, Володимир Манжос, Володимир Воротньов, Олександр Корбан та ін.

Незважаючи на стрімкий розвиток муралізму та співпрацю художників із владою (як правило, муніципальною), в Україні відсутні державні інституції (чи віААіли при установах), які 6 опікувалися пиануванням, ко- ординацією та розвитком мистецтва міських сереАовищ. Реалізовані твори з'явикися завдяки підтримці приватних ініціатив та громадських організацій, наприклаА, очо^юваному Гео Аеросом (волонтером благодійного фонАу «Сестри перемоги») арт-проєкту «Art United Us» (2016). Арт-проєкт сприяв іАеї декомунізації та орієнтувався на успішний досвіА Будапешта зі створення міста на взірець «музею просто неба». Ще однією організацією, яка опікується муралізмом та активно долучає до цього волонтерів, є фестиваль «Mural Social Club» (організатори Юлія Островська і Олег Соснов). Вони пов'язали муралізм із політикою децентралізації, що передбачає поміпшення міського середовища віААалених спальних районів міста за допомогою муралів. Ця організація, починаючи з 2016 року, Аолучає Ао роботи у Києві митців з Італії, Іспанії, США, Франції, Греції, Чимі, Бразимії, Португамії, Росії. Обидва фестивалі доповнюють волонтерські ініціативи окремих авторів, які працюють у міському середовищі. Після 2014 року у Києві було створено декілька сотень муралів, завАяки яким розвивається туризм, поліпшується естетика та соціокультурний клімат міського середовища.

Висновки. Розвиток київського муралу є явищем глибоко закономірним у контексті соціокультурних процесів в Україні та етапів самоусвіАомиення суспільства віА невизначеності часів Перебудови до культурних і геополітичних уподобань після Майдану 2014 року. Кожен етап мав віАповіАне віАображення у мистецтві графіті, а згодом і в муралах. Активно втручаючись у міське середовище, хуАожники-муралісти спирались на Аосягнення графітистів, але одночасно й опонували анархічній природі графітизму. Муралізм віАновив порушений раніше взаємозв'язок між художником, вцадою і глядачем. Муралізм сприяв поміпшенню міського середовища та поєАнанню окремих верств суспільства навколо певних, найчастіше конструктивних, культуротворчих ідей. ЗавАяки муралізму мистецтво міського середовища Києва стало фактором міжнароАного Аіалогу митців і, ширше, вступило у міжкультурний Аіалог. Часткова інспірованість мистецтва мурамів захіАними зразками (передусім, німецькими, а також американськими) та впливами монументального мистецтва радянського періоду не скасовує його глибинно оригінального характеру. Творчим спільнотам муралістів часто притаманні волонтерська безкорисливість та громадський ентузіазм - особливо на рівні колаборації з митцями Заходу.

Перспективним виглядає подальше АосліАження мистецтва муралів щодо проявів транскультурного Аіалогу, вивчення змін міського середовища, проблематики національної самоідентифікації на тлі глобамізаційних процесів. 


\section{$\Lambda$ ітература}

1. Альтернативная культура: энциклопедия / сост. А. Аесятерик. Екатеринбург: УАьтра. Культура, 2005. 240 с.

2. Бальзак $\Lambda$. Монументальная пропаганАа // Галерея. 2011. № 1-2. C. 46-47.

3. Вишеславський Г. Українська помаранчева революція і мистецтво

// REart: Революційне мистецтво: альманах. ОАеса, 2011. С. 48-49.

4. Вишеславський Г. Художні процеси у сучасному мистецтві України 1990-х рр. // Сучасне мистецтво: наук. зб. Харків: Акта, 2008. Вип. V. С. 7-62.

5. Вишеславський Г.А., Сидор-Гібелинда О.В. Термінологія сучасного мистецтва. Означення, неологізми, жаргонізми сучасного візуамьного мистецтва України: словник. Париж; Київ: Terra incognita, 2010. $416 \mathrm{c}$.

6. Вышеславский Г. «Землею і водою будемо битися з тобою... » // Антиквар. 2015. № 5-6 (90). С. 80-91.

7. Гах I. Вандалізм проти культури: Знищено монументальні розписи Модеста Сосенка! // Образотворче мистецтво. 2019. № 3. C. 90-94.

8. ГАе разрешено рисовать граффити? // Газета по-киевски. 2005. № 142 (28.07). С. 40.

9. Гео $\Lambda$ ерос випускає нову книгу про київський стріт-арт // Telegraf. URL: https://telegraf.design/news/kyiv-street-art-vol-2 (Аата звернення: 19.06.2020).

10. Історія української культури: наук. виА.: у 5 т. / гол. реА. Б. Є. Патон. / Нац. акаА. наук України. Київ: Наукова Аумка, 2011.

Т. 5. Кн. 1. Українська культура XX - початку XXI століть / голов. реА. М.Г. Жулинський. 864 с.

11. Капустин В. За сценой Майдана. Киї: Велес, 2014. 160 с.

12. МайАан віА першої особи: Мистецтво на барикаАах / упор.

Т. Ковтунович, Т. Привалко; Укр. ін-т нац. пам'яті. Київ: К.І.С., 2016. Вип. 2.304 с.: ік.

13. Мамченкова О. Настенная живопись // Новое время страны. 2016. № 23 (24 июмя). С. 58-61. URL: https://magazine.nv.ua/ journal/2623-23-24-iyunya-2016/nastennaya-zhivopis.html (Аата обращения: 19.06.2020).

14. Мусієнко Н. Мистецтво майдану: монографія. Київ: Майстерпринт, $2015.96 \mathrm{c}$.

15. Онух $Є$. Соціопат у Аії // Український тижАень. 2017. № 37 (15-21.09). С. 50.

16. Прилуцька А. Є. Смерть символу епохи: монументальне мистецтво в ракурсі ціннісних трансформацій соціуму // Гуманітаний часопис: зб. наук. пр. 2015. №3/4. C. 92-98. URL: https://journals. indexcopernicus.com/api/file/viewByFileId/612461.pdf (Аата звернення: 19.06.2020).

17. Сидор-Гібелинда О. Муририму / / Галерея. 2004. №2-3. С. 26-27.

18. Сидоренко В.А. Візуальне мистецтво віА авангардних зрушень Ао новітніх спрямувань: розвиток візуального мистецтва України XX-XXI століття / IПСМ АМУ. Київ: ВX[стуАіо], 2008. 187 с. URL: http://mari.kiev.ua/sites/default/files/inline-images/pdfs/Sydorenko. $\operatorname{pdf}$ (Аата звернення: 19.06.2020).

19. Фоменко А. Граффити: посме авангарАа и китча // Художественный журнал. 2001. № 4. С. 53-56.

20. Юр М.В. Метамодель українського живопису: монографія / Нац. акаА мистецтв України, Ін-т проблем сучас. мистецтва. Вінниця: Твори, 2019. 428 с.

\section{References}

1. Desyaterik, D. ad. (2005) Alternativnaya kultura: entsiklopediya. Ekaterinburg: Ultra. Kultura.

2. Balzak, L. (2011) 'Monumentalnaya propaganda', Galereya, 1-2, pp. 46-47.

3. Vysheslavskyj, G. (2011). 'Ukrayinska pomarancheva revolyuciya i mystecztvo' in REart: Revolyucijne mystecztvo: almanax. Odesa: [n. p.], pp.48-49.

4. Vysheslavskyj, G. (2008) 'Khudozhni procesy u suchasnomu mystecztvi Ukrayiny 1990-x rr.' Suchasne mystecztvo, 5, pp.7-62.

5. Vysheslavskyj, G.A. and Sydor-Gibelynda, O. V. (2010) Terminologiya suchasnogo mystecztva. Oznachennya, neologizmy, zhargonizmy suchasnogo vizualnogo mystecztva Ukrayiny: slovnyk. Paris; Kyiv: Terra incognita.

6. Vyisheslavskiy, G. (2015) “'Zemleyu i vodoyu budemo bytysya z toboyu...”, Antikvar, 5-6 (90), pp. 80-91.

7. Gax, I. (2019) 'Vandalizm proty kultury: Znyshheno monumentalni rozpysy Modesta Sosenka!', Obrazotvorche mystecztvo, 3, pp. 9094.

8. 'Gde razresheno risovat graffiti?' (2005) Gazeta po-kievski, 28 November, p. 40.

9. 'Geo Leros vypuskaye novu knygu pro kyyivskyj strit-art' (2018). Telegraf [online] Available at: https://telegraf.design/news/kyiv-streetart-vol-2 (Accessed: 19 June 2020).

10. Zhulynskij, M.H. (ed.) (2011) Istorija ukraïns'kö̈ kul'tury, vol. 5, part 1, Ukraïnska kul'tura XX - počatku XXI stolit. Kyiiv: Naukova Dumka.

11. Kapustin, V. (2014) Za stsenoy Maydana. Kyiv: Veles.

12. Kovtunovych, T. and Pryvalko, T. (eds.) (2016) Majdan vid pershoyi osoby: Mystecztvo na barykadax. Kyiv: K.I.S. Ukr. in-t nacz. pamyati.

13. Mamchenkova, O. (2016) 'Nastennaya zhivopis', Novoe vremya stranyi 24 Jul., pp. 58-61. [online]. Available at: https://magazine. nv.ua/journal/2623-23-24-iyunya-2016/nastennaya-zhivopis.html (Accessed: 19 June 2020).

14. Musijenko, N. (2015). Mystecztvo majdanu = Art of the Maidan. Kyiv: Majster-prynt.

15. Onux, Ye. (2017) 'Sociopat u diyi', Ukrayinskyj tyzhden, 1521 Sep., p. 50.

16. Pryluczka, A. (2015). 'Smert symvolu epoxy: monumentalne mystecztvo v rakursi cinnisnyx transformacij sociumu', Gumanitanyj chasopys, 3-4, pp. 92-98 [online]. Available at: https://journals.indexcopernicus.com/api/file/viewByFileId/612461.pdf (Accessed 19 June 2020).

17. Sydor-Gibelynda, O. (2004). 'Muryrymu', Galereya, 2-3, pp. 26-27.

18. Sydorenko, V. (2008) Vizualne mystecztvo vid avangardnyx zrushen do novitnix spryamuvan. Rozvytok vizualnogo mystecztva Ukrayiny XXXXI stolittya [online]. Kyiv: VX [studio]. Available at: http://mari.kiev. ua/sites/default/files/inline-images/pdfs/Sydorenko.pdf (Accessed 19 June 2020).

19. Fomenko, A. (2001) 'Graffiti: posle avangarda i kitcha', Hudozhestvennyiy zhurnal, 4, pp. 53-56.

20. Yur, M. (2019) Metamodel ukrayinskogo zhyvopysu. Vinnycya: Tvory. 
Ospishcheva-Pavlyshyn M.

Contemporary Murals in Kyiv Urban Space

Abstract. In the second half of the 1980s, the USSR underwent significant ideological, economic and sociocultural changes, which were accompanied by the emergence of independent Ukraine and formation of civil society. These stages of development were reflected in the culture and, in particular, in the art of the urban environment, the manifestations of which are graffiti and murals. The formation and developmental stages of contemporary muralism, and also its relationship with sociocultural processes are have not yet received proper attention in academic literature.

The aim of the article is to study the emergence and developmental stages of the contemporary muralism in Kyiv in the broad context of post-Soviet cultural genesis.

The features of graffiti art and muralism are investigated using chronological analysis and synthesis, systematic approach and comparative method. The text highlights the influence of Western, Soviet and authentic Ukrainian cultures on the worldview and aesthetics of Kyiv muralists and analyzes the social activities of muralists as volunteers.

Keywords: muralism, graffiti, Kiev muralism, sociocultural activity of muralists.

\section{Оспищева-Павлишин М.}

Творчесская и социокультурная Аеятельность современных художников-муралистов в Киеве

Аннотация. Целью работы явмяется изучение специфики появления и этапов развития современного мурализма в Киеве в широком контексте культурогенеза постсоветского времени. Прослеживается, как художники-муралисты опирались на Аостижения граффитистов, одновременно оппонируя анархической природе граффитизма. Следствием участия в исторических событиях посреАством творчества (созАание мотивационных изображений, разработка новой эстетики, воплощение идей Майдана в визуальных образах) Аля многих муралистов было возобновление разорванной ранее связи между художником, вмасть и зрителем. Используя хронологический анализ и синтез, системный поАхоА и компаративный метоА, исследуются особенности графитизма и мурализма. В тексте освещены влияния западной, советской и аутентичной украинской культур на мировоззрение и эстетику творчества муралистов Киева, проанализирована социальная деятельность художников-муралистов в качестве волонтеров. Ключевые слова: мурализм, граффити, киевский мурализм, социокультурная деятельность муралистов. 